\title{
The effect of corporate social responsibility, profitability, independent commissioners, sales growth and capital intensity on tax avoidance
}

\author{
Astrid Faradisty \\ Faculty of Economics and Business, Universitas Riau, Pekanbaru, Indonesia \\ astrid.faradisty@lecturer.unri.ac.id \\ Eka Hariyani \\ Faculty of Economics and Business, Universitas Riau, Pekanbaru, Indonesia \\ Meilda Wiguna \\ Faculty of Economics and Business, Universitas Riau, Pekanbaru, Indonesia
}

Follow this and additional works at: https://journal.uii.ac.id/jca

Copyright (C2019 Journal of Contemporary Accounting and Authors.

Astrid Faradisty, Eka Hariyani, \& Meilda Wiguna. (2019). The effect of corporate social responsibility, profitability, independent commissioners, sales growth and capital intensity on tax avoidance. Journal of Contemporary Accounting, 1(3), 153-160. doi:10.20885/jca.vol1.iss3.art3 


\title{
The effect of corporate social responsibility, profitability, independent commissioners, sales growth and capital intensity on tax avoidance
}

\author{
Astrid Faradisty ${ }^{1}$, Eka Hariyani², Meilda Wiguna
}

Faculty of Economics and Business, Universitas Riau, Pekanbaru, Indonesia

\section{JEL Classification: \\ M14, H26 \\ Keywords: \\ tax avoidance, corporate social responsibility, sales growth, capital intensity.}

\section{Corresponding Author:}

astrid.faradisty@lecturer.unri.ac.id

DOI:

10.20885/jca.vol1.iss3.art3

Copyright (C2019

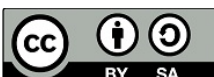

This is an open access under CC-BY-SA LICENSE

\begin{abstract}
This study aims to examine and determine the effect of corporate social responsibility, profitability, independent commissioner and sales growth on tax avoidance. The sampling method used in this study was the purposive sampling method for the period 2015-2017 in the Indonesian stock exchange at 154 manufacturing companies and 32 samples with multiple regression analysis. The results shows that the variables of corporate social responsibility, independent commissioner, and sales growth variables have an effect on tax avoidance. On the other hand, the variables of profitability and capital intensity does not affect tax avoidance. For future studies it is necessary to add an independent variable to see its effect on tax avoidance and to compare it with samples in other sectors outside manufacturing companies.
\end{abstract}

\section{Introduction}

In 2017, tax income made 89 percent of state revenue in APBN (Kementerian Keuangan Republik Indonesia, 2018). Based on Economy.okezone.com (2015), tax income realization in Indonesia arel

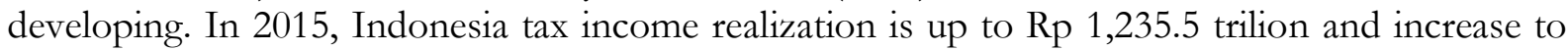
$\mathrm{Rp}$ 1,315.9 trilion in 2018. Although tax realization increased, but the target never reached every year. Therefore, the Goverment give special attention in tax sector by made an intensification and ekstensification tax policy to optimize tax sector that growth countries rate and the implementation can run well.

The government objective to maximize revenue from the tax sector contrary to the objectives of the company as taxpayers, they're trying to efficient tax cost in order to prosper the owner and company sustainability by optimize the profit (Yoehana, 2013). Different of interest impact the company to do tax avoidance. The higher the level of awareness owned by the taxpayers running business, the higher their level of compliance (Meidawati \& Azmi, 2019). Tax avoidance is the effort to avoid the tax in legal way cause not contradict with tax regulation, utilizing grey area in tax regulation to minimize the tax payment (Pohan, 2013). The measurement of tax avoidance in this paper use cash effective tax rate (CETR). The higher percentage of CETR close to 25 percent company tax indicate the lower percentage company to do tax avoidance, and vice versa.

In 2014, Indonesia Coca Cola limited minimize tax payment and cause Rp 49.24 billion deficiency of tax payment. Tax Ministry of Indonesia investigated that the company do the tax avoidance that cause swelling enormous expanse to companies. The bigger the expenses, the smaller the tax payment. One of the expanse is marketing expanse in 2002-2006 as much Rp566.84 miliar. So that decreasing company taxable income (Kompas.com, 2014). 
Based on the cases that occur, tax avoidance is common in Indonesia. There are several factors that influence tax avoidance. Corporate Social Responsibility (CSR) as commitment in private sector to responsibility as an economic, social and ecologic not only to prevent negative effect that could happen in the future, but also to improve society an environment around company as stakeholder (Lako, 2011). Watson (2015) said that company which has poor CSR is considered as unresponsible company and has the higher probability to do tax avoidance compared to company that has good CSR. The company that has good CSR realize that tax can be huge contribute to society and state. Pradipta and Supriyadi (2015) dan Muzakki and Darsono (2015) showed that CSR has negative impact in tax avoidance, if company has high level of CSR mean that company has low level to do tax avoidance. Reinaldo et al. (2017) said Corporate Social Responsibility (CSR) has no effect to tax avoidance, in other word, wheather high or low level CSR has zero impact to company to do or not to do tax avoidance.

Profitability is a ratio to measure company capability to get profit (Kasmir, 2014). Profitability can showed by return on aset ratio (ROA). Through ROA, company can measure they capability to use their asset efficiently in term to get profit. The higher ROA mean that the better company performance (Kurniasih \& Sari, 2013). Waluyo et al. (2015) showed that ROA has effect to tax avoidance, because company can maintenance aset very well, one of them by using depreciation and amortitation to reduce taxable income. Because of that, company has advantage likes tax incentive and other tax concession. At the end, the company looks like do the tax avoidance. It is in line with research conducted by Pradipta and Supriyadi (2015) and Kurniasih and Sari (2013) which state that profitability has a significant effect on tax avoidance. But different result showed by Ardyansah and Zulaikha (2014), that profitability has no effect on tax avoidance.

Furthermore, through an independent commissioner, it is expected that the activities carried out by the company will not deviate from the provisions of the established regulations. The more number of independent commissioners, the supervision of company management becomes increasingly strict, so the probability to do tax avoidance is lower (Pradipta \& Supriyadi, 2015). Putra and Merkusiwati (2016) and Ardyansah and Zulaikha (2014) shows the independent commissioner variable has a significant effect on tax avoidance, with the existence of an independent commissioner who carries out a supervisory function well on the company's management, it will reduce the level of tax avoidance by the company. Different results are shown by research by Agusti (2014) and Kurniasih and Sari (2013) which states that independent commissioners have no effect on tax avoidance, the existence of an independent commissioner cannot influence the management or the board of commissioners in making operational decisions of the company.

Horne and Wachowicz (2008) said the theory that the level of sales growth is the result of a comparison between the difference in sales in the current year and sales in the previous year with sales in the previous year. Dewinta (2016) state that sales growth can describe the good or bad level of sales of a company. Companies can predict how much profit will be obtained by the size of sales growth. An increase in sales growth will tend to make the company get a large profit, and therefore the company will tend to practice tax avoidance.

Capital intensity ratio is investment activities undertaken by companies that are associated with investments in the form of fixed assets and inventories (Siregar \& Widyawati, 2016). Rodríguez and Arias (2012) state that fixed assets owned by companies allow companies to cut taxes as a result of depreciation of fixed assets each year. This shows that companies with high levels of fixed assets have lower tax cost compared to companies that have low fixed assets. Muzakki and Darsono (2015) and Purwanti and Sugiyarti (2017) states that capital intensity ratio has a significant effect on tax avoidance. However, it is different from the results of research conducted by Putra and Ni Ketut (2016) and Ardyansah and Zulaikha (2014) which states that there is no effect of capital intensity ratio on tax avoidance.

This study is a development of research conducted by Pradipta and Supriyadi (2015) and Purwanti and Sugiyarti (2017) by taking the CSR variable, profitability, independent commissioners, 
sales growth and capital intensity on tax avoidance in manufacturing companies on the Indonesia Stock Exchange. The reason for taking variables is because there are still inconsistencies in results from previous studies. The purpose of this study is to examine and determine the effect of corporate social responsibility, profitability, independent commissioners and sales growth on tax avoidance. This research uses a proxy CETR in measuring tax avoidance because the CETR can assess tax payments from the cash flow statement, so we can find out how much cash is actually paid by the company, whereas previous research used effective tax rate (ETR).

\section{Literature Review}

\section{The Effect of Social Responsibility and Tax Avoidance}

In general, Corporate Social Responsibility (CSR) is seen as an ongoing commitment in the business world to be responsible economically, socially, and ecologically to prevent negative impacts that may occur and to improve the quality of communities and the environment as company's stakeholders (Lako, 2011). CSR leads to a close attachment to the environment, so that its responsibility for the environment is better, such as pollution control, reforestation programs, conservation of natural resources, and other environmental programs (Najamuddin, Haryanto, \& Hamdani, 2019). Companies that choose to engage in CSR activities are likely to take lower tax avoidance measures. Because, CSR activities are actions that not only take into the economically but also socially, environmental and other impacts of actions taken by the company itself as a form of responsibility to stakeholders. High CSR disclosure shows that the company fulfills its obligations both economically and socially, it is expected that the lower the level of the company doing tax avoidance. From the description above, the hypothesis can be formulated as follows:

$\mathbf{H}_{1}$ : Corporate social responsibility effect on tax avoidance

\section{The Effect Profitability and Tax Avoidance}

Profitability is the company's ability to get profit from the activities of the company. Lanis and Richardson (2012) states that the greater the profits derived by the company, it will affect the amount of income tax that must be paid. Companies with high profitability indicate that the company has good tax planning so as to obtain optimal tax, this results likely show the tendency of companies to do tax avoidance will decrease. Then, hypothesis can be formulated as follows:

$\mathbf{H}_{2}$ : Profitability effect on tax avoidance

\section{The Effect of Independent Commissioner and Tax Avoidance}

Based on research of Putra and Merkusiwati (2016) and Ardyansah and Zulaikha (2014) independent commissioners carrying out supervision and determining short-term and long-term policy strategies that benefit the company but do not violate the law, including tax-related strategies. The more independent commissioners in a company will prevent the company in taking tax avoidance so that the CETR becomes high, because by carrying out the supervisory function the independent commissioner can influence the management to make good financial reports. From the description above, the hypothesis can be formulated as follows:

$\mathbf{H}_{3}$ : Independent commissioner effect on tax avoidance

\section{The Sales Growth Effect and Tax Avoidance}

The Sales Growth is changes in sales from year to year or from time to time. Sales growth is measured by comparing last year's sales minus current years with current year's sales. The higher the level of sales growth, the better sales growth by companies. Companies with high sales growth rates, will has impact on high profits (Heryuliani, 2015). 
By increased sales growth, will cause the company to get a high profit, the higher the profit the company gets, the higher tax that should be paid. In other word, companies would tendence to do tax avoidance. From the description above, the hypothesis can be formulated as follows:

$\mathbf{H}_{4}$ : Sales Growth effect on tax avoidance

\section{The Effect Capital Intensity and Tax Avoidance.}

Based on Comanor and Wilson (1967) capital intensity ratio is one of the important information for investors because it can show the efficiency of the capital that invested. According to Yoehana (2013) capital intensity ratio describes how much the company's wealth is invested in fixed assets.

Rodríguez and Arias (2012) state that fixed assets owned by companies allow companies to cut taxes as a result of depreciation of fixed assets each year. This shows that companies with high levels of fixed assets have lower tax cost compared to companies that have low fixed assets.

This is in line with Purwanti and Sugiyarti (2017) shows that capital intensity significantly has effect to tax avoidance. The impact of capital intensity on tax avoidance is because the depreciation cost of assets is higher, resulting in a higher cost on the company. Because of this, the profits obtained are getting smaller, so that it has an impact on small taxable income. Then, that can be indicated the company to do tax avoidance. From the description above, the hypothesis can be formulated as follows:

$\mathbf{H}_{5}$ : Capital intensity effect on tax avoidance

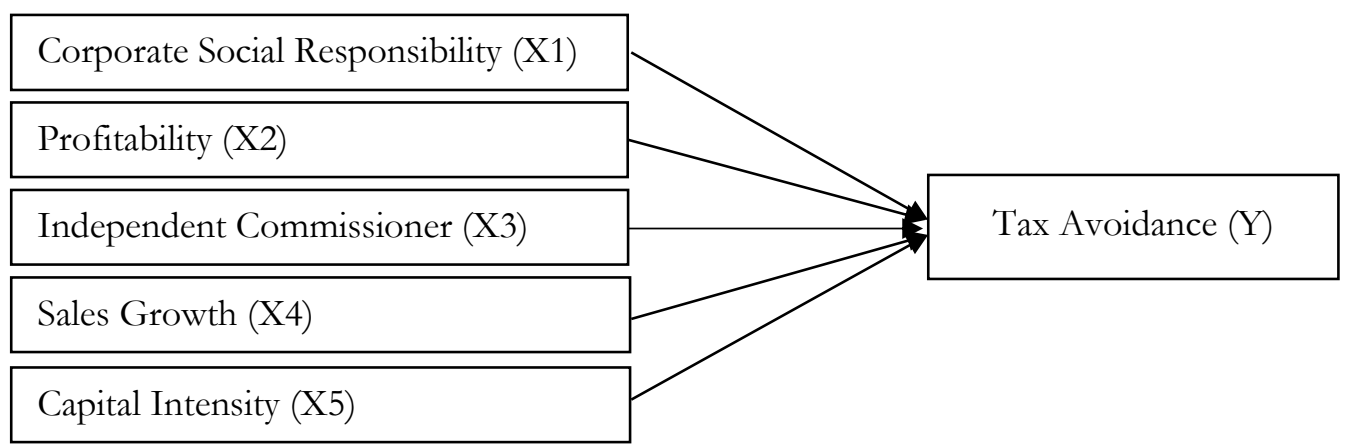

Figure 1. Research Model

\section{Research Method}

This research uses data collection methods by collecting data such as, by documenting and searching data directly from company records or documents. The secondary data needed consists of financial statements and annual reports of 154 manufacturing companies listed on the Indonesia Stock Exchange in 2015-2017 and according to sample selection criteria. The number of samples used in this research amounted to 32 companies with a total of 3 years of research.

The type of data used in this research is secondary data. Secondary data is a source of data obtained indirectly through an intermediary. Secondary data can be in the form of evidence, notes, or historical reports in archives, both published and unpublished. The secondary data sources in this research were obtained in the financial statements of the listed company on the official website of the Indonesia Stock Exchange (IDX).

This research has four independen variabels that are corporate social responsibility, profitability, independent commissioners, sales growth and capital intensity, and also has one dependen variabel, that is tax avoidance. The formula for measuring the ratio of CSR disclosures according to Lanis and Richardson (2012) is as follows:

$$
C S R D i=\frac{\sum \boldsymbol{X} \boldsymbol{i}}{\boldsymbol{n}}
$$




\section{Result and Discussion}

\section{Descriptive Analysis Results}

Descriptive statistical analysis is a statistic used to analyze data by describing data that has been collected as it is without intending to make conclusions that apply to the public or generalization.

Table 1. Descriptive Analysis Results

\begin{tabular}{lccccc}
\hline \multicolumn{6}{c}{ Descriptive Statistics } \\
\hline CSR & $\mathrm{N}$ & Min & Max & Mean & Std. Deviation \\
PROFIT & 96 & .044 & .352 & .16970 & .068178 \\
KOM & 96 & .002 & .382 & .10319 & .083860 \\
SG & 96 & .333 & .800 & .41173 & .113118 \\
TA & 96 & .003 & .532 & .09696 & .082744 \\
Valid N (listwise) & 96 & .000 & 1.289 & .31734 & .219358 \\
\hline Source: Data by SPSS 24, 2019 & 96 & & & & \\
\hline
\end{tabular}

\section{Multicollinearity Test Result}

Multicollinearity test aims to test whether in the regression model found a correlation between independent variables. To detect whether or not there is multicollinearity in the regression model can be done by looking at the value of tolerance and Variance Inflaction Factor (VIF). If the VIF value $<10$ and Tolerance $>0.10$, it is concluded that there is no close relationship between the independent variables or multicollinearity does not occur, and vice versa. Following are the results of the multicollinearity test presented in Table 2.

Table 2. Multicollinearity Test Result

\begin{tabular}{lcc}
\hline \multirow{2}{*}{ Model } & \multicolumn{2}{c}{ Collinearity Statistics } \\
\cline { 2 - 3 } & Tolerance & VIF \\
\hline CSR & .952 & 1.051 \\
PROFIT & .951 & 1.052 \\
KOM & .958 & 1.044 \\
SG & .942 & 1.061 \\
CI & .992 & 1.008 \\
\hline
\end{tabular}

Based on Table 2, it can be seen that the tolerance value of each variable shows a number $>0.1$ and the VIF value shows $<10$, so it can be concluded that each variable has been freed from multicollinearity.

\section{Multiple Linear Regression Analysis}

Table 3. Hypothesis Testing Results

\begin{tabular}{cccl}
\hline Hypothesis & $\mathrm{t}$ & Significant & \multicolumn{1}{c}{ Result } \\
\hline $\mathrm{H}_{1}$ & 2,279 & 0,025 & Supported \\
$\mathrm{H}_{2}$ & 0,926 & 0,380 & Not supported \\
$\mathrm{H}_{3}$ & 2,294 & 0,039 & Supported \\
$\mathrm{H}_{4}$ & 3.243 & 0,007 & Supported \\
$\mathrm{H}_{5}$ & 0,350 & 0,972 & Not supported \\
\hline
\end{tabular}

The hypothesis is tested using multiple linear regression models to obtain a comprehensive picture of the effect of corporate social responsibility, profitability, independent commissioners, sales growth and capital intensity on tax avoidance (see Table 3). 


\section{The Effect of Social Responsibility to Tax Avoidance}

From the results of testing the $\mathrm{H} 1$ significant $0.025<0.05$. Based on these results it can be concluded that the first hypothesis is supported, corporate social responsibility affects tax avoidance. So, the higher level of CSR disclosure of a company mean the minimum tax avoidance, wich is the indicated by the smaller CETR. Based on stakeholder teory that the activities company not also for their own interest but also for the interests of all parties or stakeholders affected by the company's activities By paying taxes with full awareness and in accordance with the stipulated nominal, the company has also developed good relations with the government. This is supported by the theory of legitimacy in which corporate social responsibility is a form of means of obtaining legitimacy from all its stakeholders, the higher the level of disclosure of a company's corporate social responsibility, the higher the company's reputation in the eyes of the community. Tax is a form of corporate social responsibility to its stakeholders through the government.

\section{The Effect Profitability to Tax Avoidance}

Based on that these result it can be concluded that the $\mathrm{H} 2$ is not supported, which means profitability not affect on tax avoidance, because it is suspected that companies in Indonesia have overpayments of tax that are compensated for in the next year's tax payments, which causes the tax payments for that year to be small and there is also a fiscal correction of expenses that are not recognized in the Taxation Law which causes tax payments to become big.

\section{The Effect of Independent Commissioner to Tax Avoidance}

Based on these results it can be concluded that the $\mathrm{H} 3$ is supported, which mean independent commissioner affect tax avoidance. The Indonesian Stock Exchange Regulation (Kep $305 / \mathrm{BEJ} / 07-2004$ ) states that the number of independent commissioners a company must have is at least 30 percent of the board of commissioners. The more independent commissioners in a company, the lower the tax avoidance the company does, so that the CETR will be greater. This is due to the fact that the independent commissioner has performed a good supervisory function on the company's management to compile quality financial reports so that the company does not implement a tax avoidance strategy.

\section{The Sales Growth Effect to Tax Avoidance}

Based on these results it can be concluded that the $\mathrm{H} 4$ is supported, which mean sales growthaffect tax avoidance. The higher the growth of a sale, the lower the tax avoidance carried out by the company, so that the CETR is also higher. Because, high sales growth indicates high profits in the company so that it is able to contribute to management not to do corporate tax avoidance.

\section{The Effect Capital Intensity to Tax Avoidance}

Based on that these result it can be concluded that the H5 is not supported. Capital intensity not affect tax avoidance. The number or at least of fixed assets owned by a company has no effect in determining whether the company is doing tax avoidance. And also, because it is suspected that companies in Indonesia have fixed assets that have passed the time limit specified in the Taxation Law to be depreciated, so that in fiscal terms there is no longer any depreciation expense that can be deducted from income.

\section{Conclusion}

Referring to the analysis results and discussion, it can be concluded that CSR, independent commissioners, sales growth affects tax avoidance. On the other hand, profitability and capital 
intensity does not affect tax avoidance. So, the higher level of CSR disclosure of a company mean the minimum tax avoidance, wich is the indicated by the smaller CETR. Based on stakeholder teory that the activities company not also for their own interest but also for the interests of all parties or stakeholders affected by the company's activities By paying taxes with full awareness and in accordance with the stipulated nominal, the company has also developed good relations with the government profitability not affect on tax avoidance, because it is suspected that companies in Indonesia have overpayments of tax that are compensated for in the next year's tax payments, which causes the tax payments for that year to be small and there is also a fiscal correction of expenses that are not recognized in the Taxation Law which causes tax payments to become big.

Furthermore, the more independent commissioners in a company, the lower the tax avoidance the company does, so that the CETR will be greater. This is due to the fact that the independent commissioner has performed a good supervisory function on the company's management to compile quality financial reports so that the company does not implement a tax avoidance strategy. The higher the growth of a sale, the lower the tax avoidance carried out by the company, so that the CETR is also higher. Because, high sales growth indicates high profits in the company so that it is able to contribute to management not to do corporate tax avoidance. And the last, The number or at least of fixed assets owned by a company has no effect in determining whether the company is doing tax avoidance. And also, because it is suspected that companies in Indonesia have fixed assets that have passed the time limit specified in the Taxation Law to be depreciated, so that in fiscal terms there is no longer any depreciation expense that can be deducted from income.

This research is limited to the data used, which are secondary data. This research uses a sample of 32 manufacturing companies and this study uses five independent variable influences on the dependent variable. For further research, it is necessary to add an independent variable to see its effect on tax avoidance and to compare it with samples in other sectors outside manufacturing companies.

\section{References}

Agusti, W. Y. (2014). Pengaruh profitabilitas, leverage, dan corporate governance terhadap tax avoidance (studi empiris pada perusahaan manufaktur yang terdaftar di BEI tahun 20092012). Jurnal Akuntansi, 3(2), 1584-1613.

Ardyansah, D., \& Zulaikha, Z. (2014). Pengaruh size, leverage, profitability, capital intensity ratio dan komisaris independen terhadap effective tax rate (ETR). Diponegoro Journal of Accounting, 3(2), 371-379.

Comanor, W. S., \& Wilson, T. A. (1967). Advertising market structure and performance. The Review of Economics and Statistics, 49(4), 423-440.

Dewinta, I. A. R. (2016). Pengaruh Ukuran Perusahaan, Umur Perusahaan, Profitabilitas, Leverage dan Pertumbuhan Penjualan Terhadap Tax Avoidance. E-Jurnal Akuntasi Universitas Udaya, 14(3), 1584-1613.

Economy.okezone.com. (2015, March). Penerimaan Pajak Lima Tahun Terakhir Tak Capai Target. Retrieved from https://economy.okezone.com/read/2015/03/23/20/1122994/penerimaan-pajak-limatahun-terakhir-tak-capai-target. Accessed 20 December 2018.

Heryuliani, N. (2015). Pengaruh Karakteristik Perusahaan dan Kepemilikan Keluarga Terhadap Penghindaran Pajak. Universitas Islam Negeri Syarif Hidayatullah.

Horne, J. C. Van, \& Wachowicz, J. M. (2008). Fundamentals of Financial Management. Pearson Education Limited.

Kasmir. (2014). Analisis Laporan Keuangan. Jakarta: Raja Grafindo Persada.

Kementerian Keuangan Republik Indonesia. (2018). APBN Kita Kinerja dan Fakta. Jakarta. 
Kompas.com. (2014, June). Coca-Cola Diduga Akali Setoran Pajak. Retrieved from https://ekonomi.kompas.com/read/2014/06/13/1135319/CocaCola.Diduga.Akali.Setor an.Pajak. Accessed 20 December 2018.

Kurniasih, T., \& Sari, M. M. R. (2013). Pengaruh return on assets, leverage, corporate governance, ukuran perusahaan dan kompensasi rugi fiskal pada tax avoidance. Buletin Studi Ekonomi, 18(1), 58-66.

Lako, A. (2011). Dekonstruksi CSR dan Reformasi Paradigma Bisnis \& Akuntansi: Suatu Tinjauan. Jakarta: Erlangga.

Lanis, R., \& Richardson, G. (2012). Corporate social responsibility and tax aggressiveness: An empirical analysis. Journal of Accounting and Public Policy, 31(1), 86-108. https://doi.org/10.1016/j.jaccpubpol.2011.10.006

Meidawati, N., \& Azmi, M. N. (2019). Factors influencing the compliance of taxpayers. Journal of Contemporary Accounting, 1(1), 26-37. https://doi.org/10.20885/jca.vol1.iss1.art3

Muzakki, M. R., \& Darsono. (2015). Pengaruh corporate social responsibility dan capital intensity terhadap penghindaran pajak. Diponegoro Journal of Accounting, 4(3), 1-8.

Najamuddin, Y., Haryanto, P. D., \& Hamdani, R. (2019). CSR disclosure between conventional banks and Sharia banks: a comparative analysis. Religacion. Revista de Ciencias Sociales y Humanidades, 4(17), 547-554.

Pohan, C. A. (2013). Manajemen Perpajakan. Jakarta: Gramedia Pustaka Utama.

Pradipta, D. H., \& Supriyadi. (2015). Pengaruh Corporate Social Responsibility, Profitabilitas, Leverage, dan Komisaris Independen Terhadap Praktik Penghindaran Pajak. In Simposium Nasional Akuntansi XVIII. Yogyakarta: Ikatan Akuntan Indonesia Kompartemen Akuntan Pendidik (IAI KAPd).

Purwanti, S. M., \& Sugiyarti, L. (2017). Pengaruh intensitas aset tetap, pertumbuhan penjualan dan koneksi politik terhadap tax avoidance (studi kasus pada perusahaan manufaktur yang terdaftar di Bursa Efek Indonesia tahun 2012-2016). Jurnal Riset Akuntansi dan Keuangan, 5(3), 1625-1642.

Putra, I. G. L. N. D. C., \& Merkusiwati, N. K. L. A. (2016). Pengaruh komisaris independen, leverage, size dan capital intensity ratio pada tax avoidance. E-Jurnal Akuntansi Universitas Udayana, 7(1), 690-714.

Reinaldo, R., Zirman, Z., \& Rusli, R. (2017). Pengaruh leverage, ukuran perusahaan, ROA, kepemilikan institusional, kompensasi kerugian fiskal, dan CSR terhadap tax avoidance pada perusahaan manufaktur subsektor makanan dan minuman terdaftar di BEI 2013 2015. Jurnal Online Mahasiswa Fakultas Ekonomi Universitas Riau, 4(1), 45-59.

Rodriguez, E. F., \& Arias, A. M. (2012). Do business characteristics determine an effective tax rate? The Chinese Economy, 4(6), 60-83. https://doi.org/10.2753/CES1097-1475450604

Siregar, R., \& Widyawati, D. (2016). Pengaruh karakteristik perusahaan terhadap penghindaran pajak pada perusahaan manufaktur di BEI. Jurnal Ilmu dan Riset Akuntansi, 5(2), 1-17.

Waluyo, T. M., Basri, Y. M., \& Rusli. (2015). Pengaruh return on asset, leverage, ukuran perusahaan, kompensasi rugi fiskal dan kepemilikan institusi terhadap penghindaran pajak. In Simposium Nasional Akuntansi ke XVIII. Medan: Ikatan Akuntan Indonesia Kompartemen Akuntan Pendidik (IAI KAPd).

Watson, L. (2015). Corporate social responsibility, tax avoidance, and earnings performance. Journal of the American Taxation Association, 37(2), 1-21. https://doi.org/10.2308/atax-51022

Yoehana, M. (2013). Analisis pengaruh corporate social responsibility terhadap agresivitas pajak. Universitas Diponegoro. 